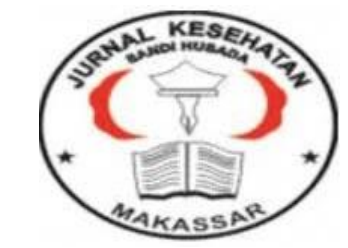

\author{
Jurnal Ilmiah Kesehatan Sandi Husada
}

hhttps://akper-sandikarsa.e-journal.id/JIKSH

Volume 9, Nomor 1, Juni 2020, pp;512-516

p-ISSN: 2354-6093 dan e-ISSN: 2654-4563

DOI: $10.35816 /$ jiskh.v10i2.343

\title{
Deteksi Dini Risiko Diabetes Melitus Pada Staff Pengajar Stikes Megarezky Makassar
}

Early Detection of Diabetes Mellitus Risk in Stikes Megarezky Makassar Teaching Staff

\section{Irwansyah Irwansyah ${ }^{1}$, Ilcham Syarief Kasim ${ }^{2}$}

${ }_{1}^{1}$ Program Studi S1 Keperawatan, Fakultas Keperawatan dan Kebidananan

Universitas Megarezky Makassar, Indonesia

2Program Studi S1 Keperawatan, Fakultas Keperawatan dan Kebidananan

Universitas Megarezky Makassar, Indonesia

\section{Artikel info \\ Artikel history:}

Received; Mei 2020

Revised: Juni 2020

Accepted; Juni2020

\begin{abstract}
Abstrak
Diabetes Melitus merupakan penyakit yang disebabkan kurangnya atau ketidak mampuan pangkreas memproduksi insulin sama sekali dalam darah sehingga menimbulkan berbagai komplikasi yang berujung pada kematian. Penderita Diabetes Melitus selalu meningkat pada tiap tahun dan diperkiraan pada tahun $2030 \mathrm{di}$ Indonesia akan mencapai 21, 3 juta. Tujuan penelitian : Untuk mendeteksi dini risiko Diabetes Melitus pada staf pengajar Stikes Mega Rezky Makassar Metode Penelitian adalah Deskriptif Analitik dengan 42 responden dengan tehnik propusive sampling, data dikumpul menggunakan lembar observasi responden dan hasil penelitian dianalisis dalam bentuk univariat.Hasil penelitian Terdapat 23 responden (55\%)yang memiliki kadar gula darah normal, 13 responden (31\%) yang beresiko Diabetes Melitus Tipe II dan terdapat 6 responden ( 14 \%) yang teridentifilasi sebagai penderita Diabetes Melitus. Implikasi Penelitian: Dapat dijadikan referensi pembelajaran, penelitian dan pengembangan keilmuan terkait Kesimpulan. Terdapat 13 responden (31\%) beresiko Diabetes Melitus Tipe 2 Saran Diharapkan seluruh Staff Pengajar Stikes Mega Rezky Makassar untuk menerapkan pola hidup sehat sebagai cara untuk menurunkan risiko Diabetes Melitus.
\end{abstract}

\section{Abstract}

Diabetes mellitus is a disease caused by a lack or inability of the pancreas to produce insulin at all in the blood, causing various complications that lead to death. Diabetes mellitus sufferers are increasing every year and it is estimated that in 2030 in Indonesia it will reach 21.3 million. Research Objectives: To detect the risk of diabetes mellitus early on the teaching staff of the Mega Rezky Stikes Makassar Research Method is Descriptive Analytic with 42 respondents with propusive sampling technique, data were collected using respondent observation sheets and the results of the study were analyzed in a univariate form. Research results There were 23 respondents (55\%) who have normal blood sugar levels, 13 respondents (31\%) are at risk of Type II Diabetes Mellitus and there are 6 respondents (14\%) who are identified as sufferers of Diabetes Mellitus. Research Implications: Can be used as a reference for 
learning, research and scientific development related to conclusions. There are 13 respondents (31\%) at risk of Type 2 Diabetes Mellitus Suggestions It is expected that all of the Stikes Mega Rezky Makassar teaching staff to implement a healthy lifestyle as a way to reduce the risk of diabetes mellitus.

\author{
Keywords: \\ Deteksi Dini; \\ Insulin; \\ Tec C Peptide; \\ Risiko Diabetes Melitus
}

Corsponden author:

Email: risawoha@gmail.com

artikel dengan akses terbuka dibawah lisensi BCC BY NC ND-4.0

\section{Pendahuluan}

Diabetes melitus merupakan penyakit yang tidak menular yang disebabkan oleh kerusakan pangkreas atau berkurangnya insulin yang diproduksi oleh pangkreas sehingga terjadi peningkatan kadar gula didalam darah atau resistensi insulin Yang menjadi masalah kesehatan terbesar dunia saat ini yang menjadi salah satu faktor penyebab turunnya kualitas sumber daya manusia ( Nurisnani \& Ratnasari, 2018 ). Pada dasarnya diabetes terbagi menjadi beberapa tipe diantaranya adalah DM tipe I dan DM tipe II dengan prevalensinya tiap tahun selalu terjadi peningkatan yang cukup sgnifikan hal tersebut tergambar pada tahun 1994 jumlah penderita diabetes dunia sebanyak 110,4 dan meningkat pada tahun 2010 menjadi 175,4 juta atau sekitar 1,5 kali lipat, pada tahun 2010 menjadi 239, 3 juta dan diperkirakan padatahun 2030 penderita diabetes akan diperkirakan menjadi 366 juta sebagai penyebab kecacacatan, kesakitan dan kematian ( Cleonara Yanur Dani, 2017 ).

Hal serupa juga disampaikan oleh WHO pada tahun 2008 dalam Global Status Report on NCDs jumlah penderita diabetes sudah mencapai 347 juta jiwa dengan presentase $80 \%$ berasal dari negara berkembang dan miskin sehingga diperkirakan pada tahun 2030 diabetes menjadi penyebab utama dari kematian penduduk dunia. Dan sebagian besar kasus diabetes berada di Indonesia dengan presentase sebagai negara ke 10 dengan tingkat penderita diabetes terbanyak bahkan pada tahun 2030 WHO memperkirakan jumlah penderita diabetes di Indonesia akan mencapai 21,3 juta penderita. (WHO, 2014 ). Peningkatan kasus diabetes di Indonesia terjadi di berbagai propinsi salah satunya adalah propinsi Sulawesi Selatan yang menempati urutan ke 4 sebagai penyakit yang tidak menular dengan presentase 6, 65 \% dan urutan kelima sebagai penyebab kematian di sulawesi selatan begituipula pada kota Makassar diabetes melitus menjadi salah satu penyebab kasus kematian dengan urutan kelima dari 10 kasus terbanyak bahkan pada tahun 2011 jumlah penderita diabetes melitus sudah mencapai 5700 dan meningkat 1300 kasus pada tahun 2012 atau 7000 kasus. (Dinkes, 2012).

Berdasarkan uraian beberapa data tersebut diabetes merupakan masalah yang perlu dikaji secara mendalam terutama dari tingkat urgensinya mulai dari serangan jantung, gagal ginjal, kebutaan, amputasi dan bahkan terdapat 10 juta penderita diabetes dunia mengalami kelumpuhan total dan pada akhirnya sangat beresiko terhadap kematian (IDF, 2014). Hal tersebut tidak disadari oleh masyarakat terutama yang memiliki tingkat kesibukan yang padat seperti pada pekerja kantoran atau staff pengajar yang rutinitas didepan layar komputer dan didalam ruangan kelas memberikan perkuliahan tentu hal tersebut sangat beresiko terhadap gangguan metabolik dan pada akhirnya Akan menderita diabetes. Hal serupa yang disampaikan oleh Nyenwe et al tahun 2003 bahwa 
rata -rata pekerja ringan dengan aktivitas fisik kurang mempunyai Kadar glukosa darah tinggi dan menderita diabetes melitus (Wahyuni S, 2010). Berbagai rutinitas dan kesibukan menjadi alasan utama bagi pekerja kantoran dan staff pengajar untuk memiliki pola hidup sehat dan bahkan memeriksakan kesehatanpun sangat jarang dilakuakan terutama yang berhubungan dengan diabetes, hal tersebut terbukti dari hasil studi pendahualuan peneliti terkait deteksi dini resiko diabetes dari 20 staff pengajar Stikes Mega Rezky Makassar dengan pernyataan pernah melakuakan tes gula darah menggunakan glukosa meter namun hal tersebut dinilai kurang efektif tampa disetai dengan pemeriksaan laboratorium yang mendalam. (Zatwal Rochman \& dkk, 2014).

Berdasarkan beberapa teori yang menyatakan bahwa Tes Insulin C Peptida adalah salah satu tes yang dinilai cukup efektif untuk mendeteksi dini Kadar glukosa dalam darah karena tes tersebut berhubungan langsung dengan tingkat Kadar insulin dalam darah. Tujuan Penelitian untuk mendeteksi dini resiko diabetes melitus pada staff pengajar Stikes Mega Rezky Makassar..

\section{Metode}

Jenis penelitian ini adalah Deskriptif Analitik yaitu hanya menganalisis satu variable tampa dihubungkan dengan variabel lain yaitu Deteksi dini risiko Diabetes Mellitus yang dilaksanakan pada tanggal 06 juni 2019 sampai dengan tanggal 06 july 2019 di Stikes Megarezky Makassar dengan jumlah populasi 189 dan 42 responden yang memenuhi kriteria sebagai sampel penelitian dengan menggunakan tehnik propusive sampling. Adapun Cara pengumpulan data dalam penelitian ini adalah menggunakan lembar obsevasi responden yang berisi karakteristik responden dan informed consent sebagai lembar persetujuan responden yang di jadikan sampel penelitian untuk dilakukan pengambilan sampel darah vena dengan menjaga kerahasian identitas dan informasi yang diberikan responden sebagi laporan hasil penelitian. Dalam penelitian ini data diolah dengan menggunakan program SPPSS 21 dalam bentuk analisis univariat yaitu menganalisis karakteristik responden dan Kadar gula darah responden yang disajikan dalam bentuk tabel hasil penelitian. (Nursalam, 2013).

Adapun prosedur penelitian ini adalah: mempersiapkan responden untuk melengkapi data karakteristik berupa kuesioner serta menandatangani Surat persetujuan sebagai responden, menginformasikan kepeda responden untuk melakukan puasa selama 10 sampai 12 jam. Mempersiapkan alat dan bahan yang dibutuhkan seperti ( spuid, kapas alkohol, turniket dan lain - lain ), mengabil darah di vena yang terletak pada lengan / punggung. Membawa sampel darah dilaboratorium untuk dianalisis. (Lika Aprilia Samadi, 2017 ). 


\section{Hasil Dan Pembahasan}

1. Distribusi responden umur, jenis kelamin,

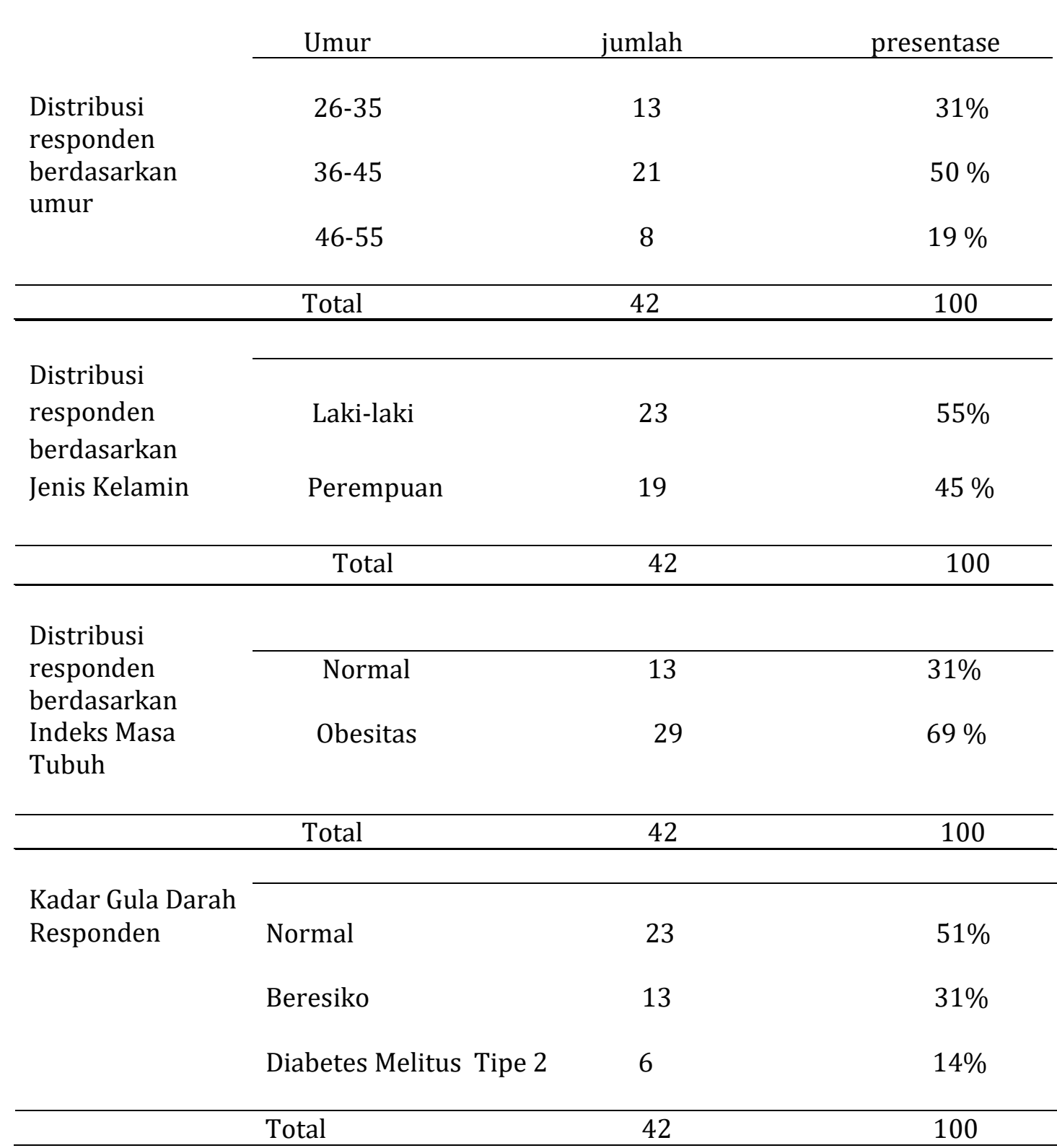

Sumber: Data primer 2019,

Sesuai dengan tujuan dari penelitian antara lain untuk mendeteksi dini risiko Diabetes Melitus pada Staff Pengajar Stikes Mega Rezky dengan Tes C Peptide yang dianggap lebih efektif dibandingkan dengan beberapa uji lainya sebagai alat ukur untuk mengidentifikasi kadar gula dalam darah antara lain Diabetes Melitus Tipe 1 , Diabetes Melitus Tipe 2, untuk mengetahui aktivitas insulin dalam darah dan bahkan disarankan untuk penderita yang teridentifikasi memiliki tanda dan gejala Diabetes Melitus dengan Nilai normal dari Tes C Peptide adalah 0,51-2,72 nanogram per mililiter Atau 0,17 -0,90 nanomoles per liter ( mnol/L). Pada dasarnya beberapa uji laboratorium atau tes gula darah mengklasifikasikan tingkat kadar gula darah kedalam tiga kelompok antara lain normal, 
beresiko dan diabetes apabila melebihi kadar normal atau standar yang telah ditentukan. Berdasarkan hasil penelitian dari 42 responden ditemukan ada 13 responden (31\%) yang teridentifikasi memiliki resiko Diabetes Melitus tipe II yang dianggap presentase tersebut cukup tinggi yang mampu mewakili dan menggambarkan bahwa prevalensi diabetes akan terus meningkat ditiap tahun. Tingginya angka kejadian Resiko diabetes Melitus bukanlah tampa alasan melainkan hal tersebut ada kaitanya dengan beberapa faktor. Pada dasarnya semua orang memiliki potensi yang sama akan beresiko diabetes melitus walaupun ada beberapa pandangan yang menyatakan bahwa diabetes melitus adalah penyakit keturunan atau faktor genetik. Namun peryataan tersebut terbantahkan oleh beberapa buku dan jurnal penelitian yang menggambarkan bahwa beberapa penyandang Diabetes Melitus Tipe II tidak semua memiliki riwayat keturunan melainkan dipengaruhi oleh beberapa faktor seperi obesitas, aktifitas fisik dan stres. (Aprilia Boku, 2019)

Secara teori menyatakan dari hasil analisis karakteristik responden berdasarkan Usia menyatakan bahwa 42 responden merupakan kelompok usia risiko Diabetes Melitus Tipe 2 yang prevalensi $90 \%$ adalah orang dewasa berbeda dengan Diabetes Melitus Tipe 1 hanya terjadi pada anak - anak yang seumur hidupnya menggunakan terapi insulin yang jumlah tidak terlalu banyak dan yang ketiga adalah Diabetes Melitus Gestotional yang hanya ditemukan pada ibu hamil, dari tiga tipe Diabetes Melitus apabila tidak ditangani cukup serius kemungkinan akan menimbulkan komplikasi yang cukup serius seperti gagal ginjal, jantung koroner, hipertensi ,stroke dan penyakit berbahaya lain. Beberapa penelitian dan teori mengungkap hal yang sama yaitu semakin meningkat umur seseorang maka semakin besar Risiko Diabetes Melitus karna usia adalah salah satu faktor yang mempengaruhi penurunan fungsi tubuh baik itu fungsi kardiovaskuler, respirasi, sistem saraf tidak terkecuali sistem endokrin yang berakibat langsung kepada kondisi insulin dalam darah.(Burner \& Sundr, 2013).

Hal yang sama yang diungkap oleh beberapa penelitian yang menyatakan ada hubungan antara usia dan kadar gula darah dimana kadar gula darah pada orang dewasa selalu dikaitkan dengan aktivitas fisik yang terbatas dengan alasan orang dewasa memiliki kesibukan bekerja, pola makan yang tidak teratur, kurang istrahat, stres dan jarang olahraga sehingga menjadi resiko tinggi terhadap Diabetes Melitus Tipe 2.( Rudi,A.,\& Kwureh, H.N, 2017). karakteristik responden yang kedua adalah jenis kelamin sebagai faktor risiko, dalam penelitian ini didominasi oleh laki-laki dengan angka 23 (55\%) dan perempuan 19 ( $45 \%$ ) . Pada kenyataanya sampai sekarang tidak ada penelitian yang menggambarkan penyebab tingginya kadar gula darah adalah dipengaruh oleh jenis kelamin walaupun secara biologis atau anatomi memiliki perbedaan akan tetapi penyandang Diabetes Melitus sama sekali tidak didominasi oleh laki-laki ataupun perempuan melainkan kasus tersebut bisa dibilang jumlahnya hampir sama, pernyataan jenis kelamin sebagai faktor risiko dibenarkan apabila hal tersebut selalu dikaitkan dengan lifestyle kebanyakan laki-laki pada umumnya memiliki lifestyle yang buruk dibandingkan perempuan beberapa tulisan mengungkap beberapa lifestyle sebagai faktor risiko Diabetes Militus Tipe 2 adalah pola makan, latihan fisik, stres, merokok dan mengkonsumsi alkohol yang berlebihan dan bahkan laki-laki biasanya sangat jarang memeriksakan kesehatanya tampa disertai tanda dan gejala yang serius. Namun menurut Nezhad et al, 2008 presentase penderita diabetes lebih didominasi oleh prempuan yang dikaitkan dengan aktivitas fisik yang kurang dibandingkan laki-laki. Beberapa pandangan juga menyebutkan istilah Diabetes Melitus selalu dihubungkan dengan hormonal yang berhubungan dengan sistem reproduksi yang pada dasarnya perempuan akan mengalami 
menopause sebagai penyebab utama penumpukan lemak sehingga sangat beresiko Diabetes Melitus Tipe 2 .( Irwan Dedi, 2010 ).

Karakteristik yang ketiga yang berkaitan dengan faktor risiko dari Diabetes Militus adalah obesitas. Pada umumnya obesitas terbagi kedalam dua kelompok hiperseluler (Dimulai semasa kanak-kanak) dan hipertrofik (Muncul setelah dewasa) yang cenderung diartikan sebagai berat badan berlebihan yang dianggap melewati standar berat badan ideal atau IMT dan beberapa literatur menyatakan obesitas dapat dinilai dengan ukuran lingkar pinggang. Kenaikan berat badan yang berlebihan atau obesitas yang pertama dipengaruhi oleh faktor genetik dan pola makan yang berlebihan yang mengandung karbohidrat yang tidak diimbangi dengan aktivitas fisik yang memperburuk keadaan sehingga dalam penelitian ini ditemukan 29 responden yang dianggap obesitas. Seiring dengan bertambahnya berat badan selalu ditandai dengan penumpukan lemak yang berakibat fatal terhadap perubahan fisiologis terutama perubahan volume darah dan fungsi jantung, fungsi paru-paru dan bahkan terjadi perombakan fungsi tubuh secara menyeluruh terutama penimbunan jaringan lemak pada abdomen (intra-abdomen) yang terlihat jelas pada lingkar pinggang yang akhirnya menjadi penyebab peningkatan kadar insulin plasma dan sindrom resisten insulin yang memberikan gangguan klinis berupa Diabetes Melitus Tipe 2. ( Arisman, 2011). Hasi penelitian yang sama yang diungkap oleh Nur isnaini dan Ratnasari dengan judul faktor resiko yang mempengaruhi kejadian Diabetes melitus Tipe dua dari 53 responden terdapat 29 responden teridentifikasi memiliki berat badan berlebih dan hasil penelitian tersebut secara statistik dengan uji korelasi ternyata memiliki hubungan yang sinifikan sehingga hal tersebut bisa dikaitkan secara teori yang menyatakan bahwa obesitas berhubungan dengan asam lemak atau Free Fatty Acid (FFA ) dalam sel yang akhirnya sebagai penyebab resistensi insulin. (Nur Isnaini \& Ratnasari, 2018 )

Selain uji laboratorium dengan analisis pembahasan yang dikaitkan dengan karakteristik responden dalam proses penelitian ini untuk mengumpulkan data diperlukan observasi dan anamnesis baik dalam bentuk wawancara dan observasi langsung keaadaan responden dengan tujuan untuk menjawab permasalahan lewat perilaku dan riwayat masa lalu responden. Beberapa hal yang tidak dijelaskan dalam karakteristik responden adalah riwayat keturunan, pola makan, pekerjaan dan beberapa faktor resiko namun dalam penelitian ini selain ditemukan 13 responden yang memiliki resiko tinggi Diabetes Melitus Tipe 2 namun dalam penelitian ini ditemukan ada 6 responden yang teridentifikasi sebagai penyandang Diabetes Melitus Tipe 2. Tingginya angka kejadian diabetes seperti dalam penelitian yang menggambarkan hanya 6 responden tentu tidak dapat mewakili untuk mendeksi semua staff pengajar di Stikes Mega Rezky Makassar dengan jumlah 189 populasi hanya 42 staff yang bisa dijadikan sampel sehingga peneliti berasumsi kejadian Diabetes Melitus dapat melebihi angka yang tertera dalam penelitian ini. Berbicara tentang Diabetes Melitus terutama Tipe 2 teori selalu mengartikan kurangnya pangkreas memproduksi hormon insulin bukan berati tidak diproduksi sama sekali sehingga biasa muncul gejala sering lapar, sering haus dan sering kencing.(Nurrahmi Ulfa, 2012). Beberapa alasan yang tertera dalam hasil anamnesis dan wawancara dari beberapa responden tidak terkecuali 6 responden yang teridentifikasi sebagai penyandang Diabetes Melitus Tipe 2 dengan hasil observasi oleh peneliti terutama pada saat istrahat beberapa staff selalu mengkonsumsi makanan yang siap saji dan mengandung gula berlebihan serta tidak terkecuali memiliki menu yang tidak imbang seperti mengkonsumsi nasi yang tidak sesuai dengan aturan diaet rendah kalori. Hal lain yang sangat menarik dalam penelitian ini kebiasaan staff pengajar laki -laki merok dan 
minum kopi dijam istrahat seakan menjadi rutinitas yang harus dijalankan dan bahkan dari 6 responden yang teridentifikasi Diabetes Melitus, 4 dari mereka adalah perokok aktif dan 2 responden adalah perokok pasif dari hasil wawancara membuktikan bahwa rata-rata responden perokok aktif menghabiskan satu bungkus perhari. ( Suyono, 2010)

Selain beberapa hal terkait sebagai faktor resiko Diabetes Melitus adalah kurangnya aktivitas fisik seperti yang telah disampaikan sebelumnya sehingga terjadi penimbunan lemak dan terjadinya penurunan produksi insulin dan bahkan aktivitas fisik yang kurang bisa memicu 4,36 kali lebih besar akan menderita Diabetes Melitus Tipe 2. Terbukti dari 6 responden ada 4 reponden yang obesitas, keterbatasan aktivitas fisik bagi pekerja kantoran merupan hal yang biasa dan menjadi sumber masalah kesehatan terutama yang berhubungan dengan resiko Diabetes Melitus tampa dicarikan solusi misalnya menggunakan waktu luang dihari libur namun pada kenyataanya beberapa responden yang teridentifikasi memiliki resiko tinggi lebih memilih untuk tidur dirumah sebagai wujud untuk menikmati hari libur.

\section{Simpulan Dan Saran}

Berdasarkan hasil penelitian dan tujuan penelitian maka dapat disimpulkan terdapat 13 responden (31\%) teridentifikasi memiliki risiko Diabetes Melitus Tipe 2 dan diharapkan kepada seluruh staff pengajar Stikes Megarezky untuk menerapkan pola hidup sehat sebagai upaya untuk menurunkan risiko Diabetes Melitus serta hasil penelitian ini diharapkan biasa dijadikan referensi dalam proses perkuliahan, penelitian dan pengembangan keilmuan terutama yang berhubungan dengan Diabetes Meltus.

\section{Daftar Rujukan}

Aprillia boku ( 2019 ). Faktor-Faktor Yang Berhubungan Dengan Kadar Gula Darah Pada Penderita Diabetes Melitus Tipe 2 di RS PKU Muhammadyah Yogyakarta. Aisyiyah Yogyakarta .

Arisman (2011). Obesitas, Diabetes Melitus dan Disilipdemia. Jakarta EGC.

Burner and sundr (2013). Buku Ajar Keperawatan Medikal Bedah Edisi 8 Volume 1. Jakarta EGC.

Cleonara Yanur Dani ( 2017 ) Asupan Vitamin C dan E Tidak Mempengaruhi Kadar Gula Darah Pasien DM Tipe II. Indonesian Jurnal of Human Nutrition

Dinas Kesehatan Kota Makassar (2012). Laporan Tahunan Dinas Kesehatan Kota Makassar Tahun 2012.

International Diabetes Federation ( 2014). Diabetes Voices, (e-journal )59 (1),

Irawan \&Dedi (2010). Prevalensi dan Faktor Resiko Kejadian Diabetes Melitus Tipe 2 di Daerah Urban Indonesia . Tesis dipublikasikan .Jakarta . Universitas Indonesia

Lika Aprilia Samiadi(2017).C-Peptida. Hello Sehat.http://hellosehat.com/kesehatan/teskesehatan/C-peptida/

Nur Isnaini \& Ratnasari. ( 2018). Faktor Resiko Yang Mempengaruhi Kejadian Diabetes Melitus Tipe 2 . Jurnal Keperawatan dan Kebidanan Aisyiyah .Vol. 14.No.1,Juni 2018.pp. 59-8.

Nurrahmi Ulfa ( 2012 ).Stop Diabetes. Yogyakarta : Familia 
Nursalam (2013 ) Metodologi Ilmu Keperawatan: Pendekatan Praktis Edisi 3. Salemba Medika;Jakarta

Nurisnani, Ratnasari (2018). Faktor Resiko Yang Mempengaruhi Kejadian Diabetes Tipe II. Jurnal Keperawatan Dan Kebidanan Aisiyah

Rudi, A.,\& Kwureh, H.N. (2017) Faktor resiko yang mempengaruhi kadar gula darah puasa pada pengguna layanan laboratorium .Volume 3 Nomor 2 Januari Tahun 2017.

Suyono (2010 ). Buku Ajar Penyakit dalam, IV Ed.Jakarta.Pusat Penerbitan Penyakit Dalam .FK UI.

WHO. 2014. World Health Statistic .Geneva : World Health Organization. Tersedia di : http://apps.who.int/iris/bistream/10665/112738/1/97892406992671 eng.

Wahyuni S ( 2010 ) Faktor -faktor yang berhubungan dengan penyakit diabetes melitus daerah perkotaan di indonesia ( Skripsi) Jakarta : Program Studi Kesehatan Masyarakat universitas Islam Negeri Syarief Hidayatullah.

Zatmal Rochman W,Prabandari Ys, Setyawati LK.(2010 ) Prevalensi Sindrom Metabolik Pada Pekerja Perusahaan. Jurnal Kesehatan Masyarakat Nasional. 2014;9(2):11320 